\title{
Can Listed Property Shares be a Surrogate for Direct Property InVESTMENT BehaViour?
}

\author{
Douw Boshoff and Chris Cloete \\ Department of Construction Economics, University of Pretoria
}

Accepted: November 2011

\begin{abstract}
The listed property sector in South Africa has grown to a size which could be considered to be a good representation of the income producing property market in general. Stock market listed property investment funds offer the opportunity to compare indirect property investment to direct property investment, which could bridge the gap between irrational investment behaviour and intrinsic asset values. This study investigates the relationship between listed property share prices and the property values in listed property funds. The share prices are correlated with various factors, such as the accounting ratios of the companies, the financial statements of the companies and general economic variables. The outcome of the study is an explanation of the behaviour of listed property shares, and its relationship to the direct property market and the general economy. This would assist in the explanation of market behaviour and provides the opportunity to more accurately predict portfolio asset values, which might be used in the valuation of individual real estate assets.
\end{abstract}

Key words: property demand, property values, macro-economic property variables, construction demand

JEL: G11

\section{1}

\section{Introduction}

Behavioural finance theory has shown that share price movement follows the irrational behaviour of the market and that the market is not as efficient as traditional economic theory would want to believe. According to Shiller (2003:102), 'The fundamental value of stocks (shares) is hard to measure, and moreover, if speculative bubbles last a long time, then even this fundamental relation may not be observed except in very long sample periods.'

The above quotation is understandable for the different listed companies that are providing various services, manufacturing and mining. Such a company should use its assets to derive an income, and the effectiveness of the management of the company will determine the amounts of profits that can be delivered. This means the more effectively the assets are utilised in mining or manufacturing processes, the more profitable the company, and theoretically the more popular it shares would be. But investors do not have the inside details of these companies and are therefore reacting differently on events that could cause the company's share price to change. This ultimately causes the share prices to be volatile, with movements that cannot always be directly correlated with specific events.

But what about listed property shares? A listed property company is not much different from a portfolio of properties owned by a number of shareholders, apart from the fact that a number of people are operating these properties on behalf of the shareholders, and the shareholders can exchange their shares on the stock exchange. Ultimately it is still a number of investors that together own a portfolio of properties. This means that the share price of a listed property fund should be stable, and theoretically mimic property values.

The outcome explains the share price of the listed property company in relation to the variables, from where it is possible to make predictions in the direct property investment market by considering activities in the indirect investment market.

The research method is based on a correlation analysis of variables identified as 
the value forming attributes in the companies under review. Although there are limited abilities in the use of correlation analysis only, it provides a good base for further research in the relationship between company equity value or share price performance and the underlying real estate assets. This study is therefore limited to an initial identification of the extent that individual items could be indicative of share price behaviour, which could then be used for further research on the topic.

\section{2}

\section{Background to the study}

'Unfortunately, property values cannot be determined by quick reference to the stock market, but have to be determined independently' (Hager \& Lord, 1985:23).

The study is done with the Listed Property market as case study, as this is a dynamic market that can provide much information on both the direct real estate investment market and the indirect and financial markets. In order to achieve this, previous research on the listed property market, property valuation and macroproperty modelling have been considered.

Hager and Lord (1985:23) noted that the shape of the return from a direct property investment is in some senses similar to that of an index-linked gilt.

Giliberto (1990:259) stated that in American Equity Real Estate Investment Trusts (EREITs), which are essentially REITs but exclude Mortgage REITs, prices track the stock market, with its attendant volatility, but they have income characteristics of direct real estate investment. Furthermore, EREIT's correlation with the stock market has declined over time, while the correlation with bond returns has increased.

Sagalyn (1990:209) found that the performance of real estate securities is driven by security market pricing. Prices react quickly to changes in the economy, and, compared to direct investments in real estate, real estate security returns are volatile.

Institutional as well as individual investors often perceive investment in listed property vehicles, or Real Estate Funds such as Property Loan Stock (PLS) or Property Unit Trusts (PUT), to be equivalent to investment in direct real estate, while retaining a degree of liquidity that is unavailable from other forms of real estate investment.

The studies mentioned above show that there are certain correlations between the behaviour of listed funds and direct real estate, but also indicate that real estate shares have similarities with the stock market in general.

The presumption is that Listed Real Estate Funds are influenced by factors similar to those influencing direct real estate. Yet the correlation between indices of listed funds and direct property investment is highly questionable (Giliberto, 1990:259). Giliberto (1990:262) showed that stock and bond market movements heavily influence EREIT's performance, but have a relatively minor effect on direct real estate investment. However, if financial market effects are removed, a strong positive correlation is evident. This suggests the presence of a common factor, or factors, in both sets of returns.

Chan, Hendershott and Sanders (1990:432) showed that three factors consistently drive both real estate and stock market returns: change in the risk structures, term structures and unexpected inflation.

According to Gyourko \& Keim (1993:39) real estate shares traded on the New York and American stock exchanges reflect changes in real estate market fundamentals in a more timely fashion than a widely used appraisalbased system. They mention that two findings are of particular relevance:

- There is no significant contemporaneous correlation between EREIT and appraisal series returns.

- EREIT returns are significantly positively correlated with broader stock market returns.

These findings have led many to conclude that share prices are not reliable guides to real estate values. They do, however, show that the stock market provides reliable return measures for one of the most important, yet least studied and understood, asset categories. They show that decisions based on movements in appraisal-based indexes rely, in large part, on stale information. The stock market, however, provides a reliable measure of real estate conditions. 
Fisher, Geltner and Webb (1994:137-160), considered the history of commercial property values by comparing different methods of constructing commercial property value indices and return series. Three types of indices were examined:

i) Indices that attempt to reconstruct property market values by 'unsmoothing' appraisal-based indices;

ii) Indices that trace average ex post transaction prices of commercial properties over time; and

iii) An index based on unlevering REIT share prices.

Under the three types, five indices of the historical value of commercial property have been quantified. Some common messages emerged from the different indices, and as the indices have been developed using different methodologies and assumptions, and to some extent different data, the conclusion is considered fairly robust.

The different indices showed a fair pattern in terms of property values over time, therefore confirming each other's findings. Some other interesting differences also emerge across the different indices, which reveal and illustrate aspects of the index construction methodology as well as the nature of commercial property markets.

All the indices show greater volatility than the appraisal-based index, with the transaction price index and REIT share price index showing visibly greater volatility than the other indices. This shows the influence of the transactions on volatility, but also contains more 'noise' than the other indices. Another interesting phenomenon is that the appraisalbased index lagged behind the REIT share price index by approximately two years, indicating that the REIT share price index registers value changes much more quickly, which might also explain the higher volatility.

Geltner (1996) introduced a RepeatedMeasures-Regression-Based Index (RMR) which allows the construction of indices of capital value at a greater frequency than the interval time between the reappraisals of the properties within the index. The RMR has been widely used in the construction of transaction price-based housing indexes in the
United States, but was not used for appraisal based indexes of commercial property. Geltner investigated the application of the method for use in appraisal-based indices of commercial property.

Peterson and Hsieh (1997:322) found that most of the evidence regarding REIT performance indicates that REITs tend to either outperform or perform about the same as common shares.

Lizieri and Satchell (1997:12) showed that property shares also exhibit a strong contemporaneous correlation with overall equity performance.

Ling and Naranjo (1999:483 \& 505-506) indicated that the market for exchange-traded real estate companies, including REITs, is integrated with the market for exchangetraded (non-real estate) shares. However, when appraisal-based returns (adjusted for smoothing) are used to construct real estate portfolio returns, the results fail to support the integration hypothesis, although this may reflect the inability of these estimated private market returns to accurately proxy for commercial real estate returns.

Glascock, Lu and So (2000:178-179) indicated that REITs and unsecuritised real estate should be cointegrated. However, cointegration between REITs and stock market may not be present because the key gains in securitised real estate may come from management and risk-sharing rather than the underlying asset of real estate per se.

Booth and Marcato (2004:147) found that the two main causes of the difference between the performance of direct real estate and real estate share indices is firstly due to the smoothing of valuation-based indices and secondly the gearing ratio of property shares or REITs indices. It was found that there is a close relationship between de-geared indirect market indices and unsmoothed direct market indices and that there is granger causality running from the indirect to the direct market. Booth and Marcato mentioned that direct real estate indices do not measure the performance of underlying transaction prices properly because they are based on valuations, and therefore maybe subject to valuation smoothing. Indirect real estate indices do not properly measure the value investors put on the 
underlying assets of real estate companies, because real estate companies are geared. They furthermore note that the analysis of the relationship between annual returns from direct real estate and annual returns from real estate shares suggests that de-geared real estate share returns have useful information content that could help understand performance in the direct real estate market. It is shown that when direct real estate data are unsmoothed, measures of dependency between the direct and the de-geared indirect market strengthen considerably, and if it is assumed that unsmoothed direct real estate returns better reflect underlying transaction prices than direct real estate data, the results suggest that data from the market for real-estate shares could be useful for filling the gaps in direct market series.

Doppegieter and Rode (2002:2) explain that PUTs' dividend yields and capitalisation rates used for valuation are not based on the same variables, and differences should be expected. They state that PUT dividend yields provide a better indication of commercial property values in South Africa than compared with cap rates.

The mentioned studies consider mostly the relationship between direct real estate investment and investment through listed vehicles by way of the similarities in the return obtained. The factors driving the return are discussed and the effect on share prices is tested and used to construct indexes to predict return behaviour, rather than value. There is also evidence of the similarities between real estate share behaviour to the behaviour of other shares. Again it is largely based on returns, rather than actual share prices or value. No evidence of studies conclusively comparing the value of shares directly to the value of the underlying real estate could be found.

Chan, Leung and Wang (1998:357) indicate that ownership structure (together with the resulting shareholder activism) has a direct impact on the ability of shareholders to monitor management's activities. In addition, this monitoring ability provided by institutional investors could affect a firm's value. They furthermore state that several studies show that the investment strategy of institutional investors has an impact on share returns and their autocorrelation.

Chan et al. (1998:357-358) continue that there are relatively fewer institutional investors investing in REIT shares than in the general stock market. In addition, REIT shares with a higher percentage of institutional ownership perform better than other REIT shares with fewer (or no) institutional investors. It therefore appears that the participation of institutional investors increases the control and monitoring ability of shareholders, and hence increases the value of REIT shares. Furthermore, there are some large institutional investors who concentrate their investments in the REIT stock market. Consequently, the monitoring and control aspects of those REITs must be improving, as institutional investors normally have the expertise and are more willing to spend resources to monitor the companies in which they invest (p. 372).

Downs and Güner (1999:518) stated that problems associated with observing the value of the underlying asset in real estate securities are frequently cited by practitioners and academics. Brennan (1990:727-728) refers to this as a latent-asset problem, in other words, the information acquisition problem of investors when the value of some assets is not observable.

Glascock, $\mathrm{Lu}$ and So (2000:177-178) indicate that as the REIT market continues to develop, institutional investors are more comfortable in this form of real estate investment, and institutional holdings of REIT IPO's have increased from less than 10 per cent before 1990 to 41.7 per cent after 1990 . This increase in institutional investment in the REIT market is partly facilitated by the tax reform act in 1993. The tax reform allows more institutional investment without jeopardising the trust's tax-favoured status. These structural changes are important to portfolio management because they may allow REITs to behave more like traditional (smallcap) shares than real estate.

Wilson and Zurbruegg (2003:205-206) indicated that with the emergence of securitised real estate as a viable alternative for institutional investors in the late 1980s and early 1990s, it has become an integral part of 
the research debate as to whether the direct and indirect property markets are driven by different forces. They state that a shortcoming in the literature appears to be a lack of effective identification of those factors that appear to have a lasting effect on moving property markets (permanent components) and those that do not (transitory components). Identifying these factors is important because:

- Institutional investors have both long- and short-term goals driven by their strategic and tactical asset allocation objectives. Isolating the objectives would provide them with more effective info to adjust their portfolios

- Securitized property markets have their underlying assets in the direct property sector. It is therefore reasonable to suppose that the permanent driving forces should be the same in both, although the transitory components may differ.

- Isolating permanent vs. transitory components will help identify the sort of controls that monetary and fiscal authorities have over domestic real estate, which again have important ramifications for institutional investors.

Doppegieter and Rode (2002:5) indicate the distinction between direct and indirect property investment as the level of involvement of investors in the actual operation of the specific building.

It is apparent from the above that the behaviour of listed property share prices are influenced by the involvement of institutional investors, and also by the amount of information that is available to them in making investment decisions.

When considering the influence of economic factors, Wilson and Zurbruegg (2003:207) state that surges in employment growth and real interest rates produce equally severe cycles in real office rents, while it was found that real Gross Domestic Product (GDP) is an important underlying component of real estate cycles for offices in Sweden.

GDP was found to be an important driver of the Canadian commercial property market (Clayton, 1996:353), while growth in real per capita consumption, real short-term interest rates, the real term structure of interest rates and unexpected inflation was found to be fundamental drivers that systematically affected returns of both direct and indirect real estate markets in the US (Ling \& Naranjo, 1997:283). In periods of expansion, the productivity level was seen as an important driver of both direct and indirect real estate markets in the US, while capital markets also played a role during periods of increased volatility (Grissom \& DeLisle, 1999:110-113). It was further found in various countries that domestic economic growth could partially explain real estate behaviour (Quan \& Titman, 1999:183) as well as interest rates and general economic fundamentals (Edelstein \& Paul, 2000:66-68; Mera, 2000:84).

Wilson et al. (2003:207-208) further indicated that there is also a growing interest in the globalisation of real estate and the identification of global drivers. There is a link between real estate cycles and growth in deregulated finance, the internationalisation of financial and economic relationships, as well as a link to fundamental economic conditions in each country. The development of closer links between real estate and capital markets and the less restricted flow of capital has spread the value cycle of real estate to a global dimension (Renaud, 1997:37). Change in world GDP is also found to be an important driver of real estate markets (Case, Goetzmann \& Rouenhorst, 2000:2-3) this was extended and it was suggested that international markets were linked to the US real estate markets through the health of the US economy (Wilson et al., 2003:208).

Lee and Stevenson (2007:551) found strong linkages between REITs and value shares, but they state that there remain sufficient differences in their return behaviour and driving forces for the two sectors to retain a level of distinctiveness, providing portfolio optimisation opportunities for which the one is not substitutable with the other.

Viezer (1998) (also Viezer, 1999) developed a Real Estate Econometric Forecast Model (REEFM). The REEFM pooled an unbalanced panel to estimate six behavioural equations for each of four property type markets (apartments, office, retail and warehouses). The six stochastic behavioural equations were occupancy, real rents, cap rate, market value 
per square foot, net change in stock, and real construction cost. REEFM integrated real estate's space and capital markets econometrically rather than diagrammatically as per previous studies (see also ArchourFischer, 1999, DiPasquale \& Wheaton, 1992 and Fisher, 1992) It significantly increased the number of metropolitan areas in the pooled equations, and estimated equations for four separate property types. REEFM also employs a unique equation for determining the change in stock of space. This equation links the space and capital markets and the short and long run by combining both price and quantity signals.

Both the REEFM and the FDW models, however, have the shortcoming that it can only do market interpretations on a macro level, in other words, to consider the long term effects of a specific type of property in a specific market. It doesn't consider the micro level influences on the property that differentiates it from other properties around it.

Boshoff (2004) furthered the application of theory to the concept of space- and capitalmarket interdependencies, by assessing the relevance of two models for real estate markets to the South African economy. The models concerned are the FDW (Fisher-DiPasqualeWheaton) model, and the REEFM (Real Estate Econometric Forecast Model). While the REEFM is an econometric model based on statistical principles that can forecast property market behaviour by interpretation of specific given variables, the FDW model provides a diagrammatic explanation of the behaviour of the property market, and while the FDW model, despite its explanatory and pedagogic merit, is of little value as an investment tool, the REEFM can forecast implicit market returns. Boshoff, by application of the REEFM to de-centralised office space in the major cities in South Africa, revealed a close correlation with actual trends, indicating that the REEFM can be used as a model for the forecasting of the office market.

Viezer (1998:1-16) indicated that there is resistance to the application of portfolio theory in real estate, due to the following:

- The nature of the real estate market, i.e. adoption of the do-the-deal principle. (p 4 8 , figure 1.1 )
- Questions regarding the quality of real estate return data (pp. 8-12)

From the above studies it is identified that various similarities between listed property shares and other shares were found in the literature, as well as between property shares and direct property, while property shares were found to be more volatile than direct real estate investment but less volatile than other shares.

Studies of direct and indirect property almost throughout consider the relationships with regard to returns on investment, while no studies were found where the actual values where compared to each other. It is indicated in the studies that if the stock market attributes could be removed from property shares, information could be obtained that could be useful in the direct property market. The latter is indicated to be unpredictable due to a lack of transparency and information, and this could therefore be well explained by indirect markets. Some studies focus on direct real estate, essentially on space and capital markets, to explain the equilibrium position and market cycles. Rather than focussing on the space and capital market equilibrium, this study considers the possibilities to obtain information from the more liquid indirect real estate market in order to explain the direct market.

\section{3}

\section{Accounting methods of valuation}

The listed property market in South Africa consists of PLS companies and Real Estate Investment Trusts, previously PUT funds. REITs in South Africa are similar to REITs elsewhere in the world, but as its assets consist largely of investment in other property vehicles (indirect real estate), the value comparison abilities between share prices and direct real estate values are diminished. As such this study is limited to PLSs which mainly invest in direct real estate.

There are 21 PLS companies, with a total market capitalisation of R93 582324 000, which is a combination of different property types, locations, and classes. As indicated in the literature, the performance of these companies would largely depend on the 
ownership structure. From the 21 companies, it was identified that eight companies had institutional shareholding of more than 40 per cent on average over the past four years. These companies were identified to show significant higher correlation in their share price movement to the movement in the JSE all-share index. The companies also dominate the PLS market in terms of size, confirming the literature on shareholder activism. One of the companies (Hospitality) focuses on leisure properties, and as such performs differently from the others. The remaining thirteen companies showed significantly less accuracy in terms of the results given in this study. As such, the focus for purposes of this paper remains on seven companies, where it was found that information is of higher availability, and the performance seems to confirm the shareholder activism theory. It was found that these seven companies holds approximately 90 per cent of the PLS sector in terms of market capitalisation and as such are considered to be a good representation of the sector. The PLS sector makes up approximately 4.1 per cent of the financial sector of which it forms part, and 0.8 per cent of the JSE.

The daily share prices of the seven PLS companies are shown in Figure 1. The similar movement for the various funds is obvious and is an indication that it might be external factors that drive the volatility of the shares, in other words, general economic conditions, or stock market confidence, rather than specific company variables.

The movement of the share prices, and ultimately the market capitalisation of the different companies, could be investigated by way of relative comparison, using the accounting method of valuation. It involves the comparison of the different accounting ratios as performance indicators to the same ratios of other companies, thereby providing a base for comparison of share performance. The financial ratios are divided into five categories:

1 Common size statement.

2 Internal liquidity (solvency)

3 Operating performance:

a) Operating efficiency;

b) Operating profitability.

4 Risk analysis:
a) Business risk;
b) Financial risk;
c) Liquidity risk.

5 Growth analysis.

Figure 1

Daily share prices of PLS companies

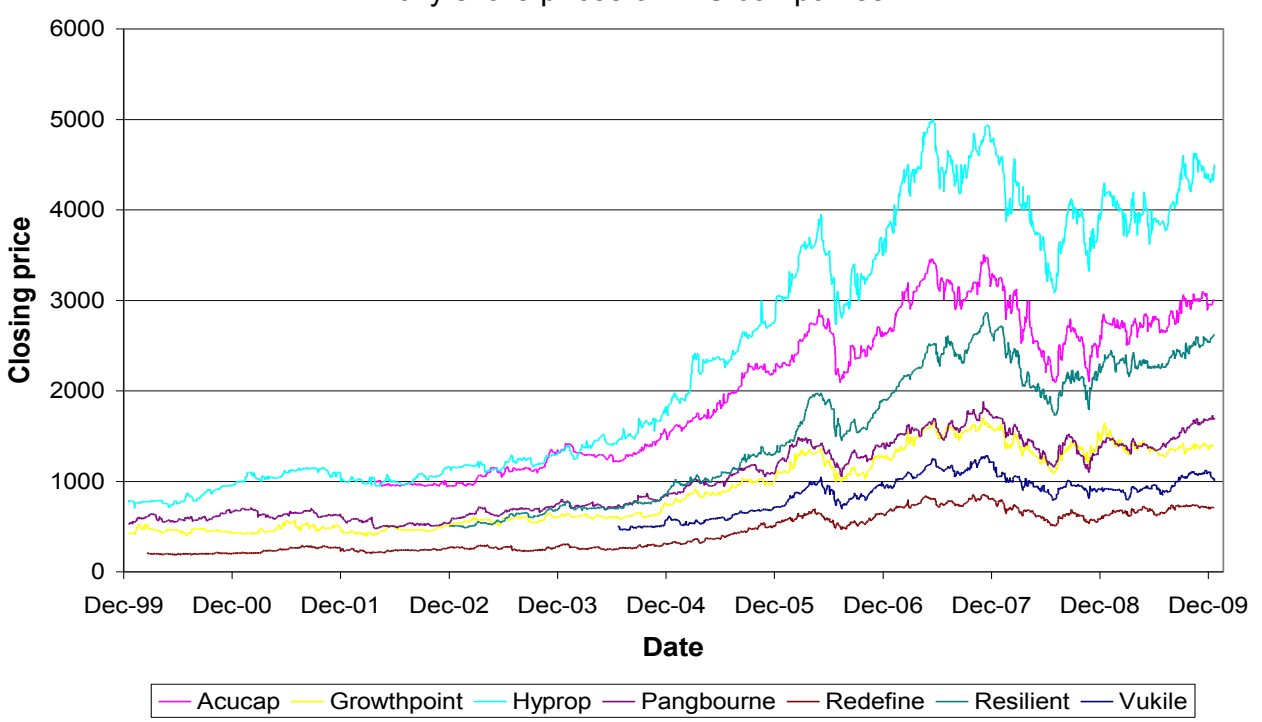

Source: McGreggor BFA 
The significance of these ratios is tested by correlation of each ratio to the share price performance over a 10 -year period from 2000 to 2009. A high positive correlation would indicate that the specific ratio is a good indicator of value driver with a positive relationship, in other words, when the ratio increases it will motivate investors to purchase the share at a higher price, while a high negative correlation indicates that an increase in the ratio would demotivate investors and subsequently the price of the share would fall.
A low correlation would indicate that an investor is indifferent to the movement of the ratio when taking a decision to buy or sell shares. The correlation of the individual companies' share prices with their respective ratios is determined, but is also combined to obtain the correlation of share prices with accounting ratios in general.

Table 1 provides the correlation coefficients for the different variables to the year-end closing price of each company.

Table 1

Accounting ratios correlation to closing share prices of PLSs

\begin{tabular}{|c|c|c|c|c|c|c|c|c|}
\hline & Acucap & $\begin{array}{l}\text { Growth- } \\
\text { point }\end{array}$ & Hyprop & $\begin{array}{l}\text { Pang- } \\
\text { bourne }\end{array}$ & Redefine & Resilient & Vukile & Combined \\
\hline Current ratio & $-.818^{*}$ & $-.698^{*}$ & .097 & .247 & .246 & -.459 & .522 & -.207 \\
\hline Debt-assets ratio & $-.979^{* *}$ & $-.738^{*}$ & $-.804^{* * *}$ & $-.907^{* *}$ & $-.974^{* *}$ & -.622 & -.826 & $-.619^{* *}$ \\
\hline Debt-equity ratio & $-.798^{*}$ & .322 & -.620 & $-.925^{\mathrm{kx}}$ & -.659 & -.616 & $-.916^{*}$ & -.130 \\
\hline Net profit margin & .079 & -.464 & .469 & .501 & .878 & -.534 & .875 & $.300^{*}$ \\
\hline Operating profit margin & .036 & -.628 & .417 & .346 & $.926^{*}$ & -.445 & .867 & $.383^{* *}$ \\
\hline Quick ratio & $-.817^{*}$ & -.560 & .097 & .008 & .246 & -.496 & .257 & -.221 \\
\hline Return on assets & -.291 & $-.816^{* *}$ & -.034 & -.050 & .120 & -.770 & .026 & .022 \\
\hline Return on capital empl. & $-.881^{* *}$ & -.482 & .035 & -.021 & -.632 & $-.973^{m *}$ & -.788 & -.245 \\
\hline Return on equity & $-.838^{*}$ & $-.728^{*}$ & $-.845^{\prime \prime \prime}$ & -.573 & -.329 & -.789 & ${ }^{\mathrm{a}}$ & $-.717^{* *}$ \\
\hline Total assets turnover & -.011 & -.483 & .233 & .515 & -.003 & -.755 & -.162 & .060 \\
\hline \multicolumn{9}{|c|}{$\begin{array}{l}\text { ** } \quad \text { Correlation is significant at the } .01 \text { level } \\
* \quad \text { Correlation is significant at the } .05 \text { level } \\
\text { a Cannot be computed because at least one of the variables is constant. }\end{array}$} \\
\hline
\end{tabular}

Source: Author

Table 2

Accounting ratios' correlation to weighted average share prices of PLSs

\begin{tabular}{|c|c|c|c|c|c|c|c|c|}
\hline & Acucap & $\begin{array}{l}\text { Growth- } \\
\text { point }\end{array}$ & Hyprop & $\begin{array}{l}\text { Pang- } \\
\text { bourne }\end{array}$ & Redefine & Resilient & Vukile & Combined \\
\hline Current ratio & $-.828^{*}$ & $-.665^{*}$ & .066 & .178 & .292 & -.467 & .214 & -.217 \\
\hline Debt-assets ratio & $-.850^{*}$ & -.618 & $-.788^{*}$ & $-.9666^{\prime \prime}$ & $-.941^{* *}$ & -.620 & $-.938^{*}$ & $-.600^{* x}$ \\
\hline Debt-equity ratio & -.718 & .044 & -.609 & $-.930^{\mathrm{mm}}$ & -.615 & -.617 & $-.881^{*}$ & -.163 \\
\hline Net profit margin & -.123 & -.354 & .412 & $.657^{*}$ & .215 & -.534 & -.257 & .253 \\
\hline Operating profit margin & -.173 & -.583 & .354 & .539 & .370 & -.445 & -.273 & $.325^{*}$ \\
\hline Quick ratio & $-.828^{x}$ & -.416 & .066 & -.038 & .292 & -.505 & -.033 & -.220 \\
\hline Return on assets & -.480 & $-.748^{*}$ & -.092 & -.058 & -.043 & -.761 & -.521 & -.052 \\
\hline Return on capital empl. & $-.885^{* *}$ & -.391 & -.005 & -.064 & $-.726^{*}$ & $-.966^{* *}$ & $-.911^{*}$ & $-.276^{*}$ \\
\hline Return on equity & $-.846^{*}$ & $-.676^{*}$ & $-.829^{* *}$ & $-.733^{*}$ & -.715 & -.777 &.$^{a}$ & $-.720^{* *}$ \\
\hline Total assets turnover & -.205 & -.386 & .183 & .536 & -.179 & -.746 & -.634 & .009 \\
\hline \multicolumn{9}{|c|}{$\begin{array}{l}\text { ** Correlation is significant at the } .01 \text { level } \\
\text { * Correlation is significant at the } .05 \text { level }\end{array}$} \\
\hline
\end{tabular}

Source: Authors 
From Table 1 it is evident that some of the ratios do provide a high level of correlation with the closing share price, but the correlation is not consistent for all companies. Where this is the case, the relevance of such a correlation is questionable. Variables that show a fair degree of consistency, as well as a high degree of correlation with combined data, are the debt-assets ratio and return on equity.

Table 2 consists of the same ratios, but the correlation is tested to the weighted average share price for the year, rather than the closing price.

Again the same ratios as with the closing price correlation test, being the debt-assets ratio and return on equity, stand out to show fairly consistent high degrees of correlation on the individual company data as well as the combined data.

In both the correlation tests, the negative correlation between the share price and the return on equity might come as a surprise: normally the higher the return on equity, the more effective is the company on its assets, and the higher the share price would be. In order to explain this reversed situation, consideration should be given to general valuation principles for income-producing properties, namely the capitalisation of the first year's income to calculate the value of the property. This is done by the formula:

\section{Value $=$ Net income/Capitalisation rate 1}

If this is rewritten in the format to determine the capitalisation rate, it is:

Capitalisation rate $=$ Net income/Value $\ldots 2$

If it is compared to the return on equity ratio, it can be seen that it is in the same format, with the total return to equity holders divided by the total value or price of the shares of the company.

This indicates that the lower the ratio of income to the asset value, the lower the capitalisation rate; or, the lower the return attributable to equity holders as percentage of the price paid for the share, the lower the return on equity ratio. The capitalisation rate in the property sector is however a measure of risk, indicating that the lower the rate, the higher the confidence of the investor that the specific asset will provide the cash flow as foreseen. Due to the fact that the PLS sector consists of a portfolio of properties, and therefore the income is the sum of the rental streams of these properties, it is therefore expected that the share price will increase as the confidence of the investors increases that the assets will deliver the required cash flow. Therefore investors are prepared to pay higher prices for the shares for a given amount of return, if they perceive the risk to decrease.

It can therefore be concluded that with PLS companies, the return on equity ratio is not an efficiency ratio as with manufacturing and other firms, but rather a confidence ratio, that will have a negative correlation with the share price of the company.

The negative correlation of the share prices with the debt-assets ratio is an indication that investors are seeing the higher debt levels as a risk to their investment, and therefore are not prepared to pay more for shares as debt increases. This indicates that the debt levels are above the optimum debt level. The structure of the PLS companies makes it difficult to analyse this variable accurately, as the total debt also includes the debentures which form part of the investment of the shareholders. Therefore this ratio should be carefully considered taking into consideration the share capital, debenture and other debt structures of each company, in other words, Growthpoint has the highest level of debt at 95.6 per cent and then Vukile at 75.8 per cent, yet Vukile has the third highest correlation between debt-equity ratio and share price (0.938 at the 95 per cent confidence level), while Growthpoint has a correlation of -0.618 but below the 95 per cent confidence level. It is evident that the debt-equity ratio is not the primary driver of share prices, and reliance is put on other factors as well. Investors seem insensitive to debt at higher levels, and therefore the debt structure of each company should be considered in more detail to get a conclusive result on this ratio. It should however be mentioned that Growthpoint is the largest of the PLS companies, while Vukile is a much smaller and volatile company. This confirms that investors would consider more than a single variable to make decisions, and would consider companies in accordance with their risk profiles.

From the above it is presumed that although 
some significant correlations are observed, the valuation of listed property funds does not entirely rely on accounting returns, and therefore confirms the criticism of various authors on the method (Van Heerden de Wet, 2004), and that reliance for value in this sector might have to be put on other variables.

\section{4}

\section{Share price correlation with financial statements}

In order to test the reliance of the share price of the PLS companies on variables other than the accounting ratios, the share price of each of the seven PLS companies under consideration is correlated with its financial statements, in other words, the balance sheet and income statements. The results of this can be seen in tables 3 to 6 .

When considering the correlations in Table 3, the share prices show significant correlations with the different balance sheet items, the most consistently high correlations as well as the highest correlations for combined data being assets, fixed assets, equity, ordinary shareholders interest and deferred tax. Although the main operation of these companies is property investment and one could expect a close correlation of the share price with fixed assets, the correlation with total assets is higher, indicating that shareholders recognise assets other than fixed assets as also important, such as investments in other companies, as these assets provide additional income. Total liabilities also provide correlations that are similar to the correlation with assets, yet the correlation of the combined data in both these cases shows a much weaker situation. This is explained by Figure 2, with debt as example, where regression lines of the individual companies can be seen, compared to the combined situation.

Table 3

Balance sheet correlation to closing share price of PLSs

\begin{tabular}{|c|c|c|c|c|c|c|c|c|}
\hline & Acucap & $\begin{array}{l}\text { Growth- } \\
\text { point }\end{array}$ & Hyprop & $\begin{array}{l}\text { Pang- } \\
\text { bourne }\end{array}$ & Redefine & Resilient & Vukile & Combined \\
\hline ASSETS & $.843^{* *}$ & $.907^{\text {*** }}$ & $.992^{* *}$ & $.751^{*}$ & $.949^{* *}$ & $.922^{* *}$ & $.981^{* *}$ & $.358^{\star *}$ \\
\hline Fixed Assets & $.855^{\mathrm{kn}}$ & $.911^{* *}$ & $.978^{\mathrm{kn}}$ & $.703^{*}$ & $.918^{* *}$ & $.901^{* *}$ & $.979^{* *}$ & $.331^{\star *}$ \\
\hline Current Assets & .408 & .622 & $.693^{*}$ & $.696^{*}$ & $.837^{* *}$ & $.696^{*}$ & $.880^{\mathrm{*}}$ & .218 \\
\hline Non Current Assets & .515 & .472 & $.851^{\prime *}$ & .399 & .445 &.$^{\mathrm{a}}$ & .559 & $.317^{\star *}$ \\
\hline Intangible Assets & .330 & .486 & $a^{a}$ & $.780^{\prime *}$ &.$^{a}$ & .456 & $.964^{\mathrm{n*}}$ & .047 \\
\hline EQUITY & $829^{\mathrm{kx}}$ & .513 & $.995^{* *}$ & $.779^{\mathrm{k*}}$ & $.927^{\mathrm{N*}}$ & $.899^{\mathrm{kx}}$ & $.921^{\prime * *}$ & $.655^{\star \star}$ \\
\hline Ordinary S.H. Interest & $829^{\prime *}$ & .513 & $.979^{k *}$ & $.760^{\circ}$ & $.927^{* *}$ & $.898^{* *}$ & $.914^{\prime *}$ & $.614^{* *}$ \\
\hline Outside S.H. Interest &.$^{\mathrm{a}}$ &.$^{a}$ & $.639^{*}$ & .306 & .445 &.$^{\mathrm{a}}$ & .149 & $.564^{\star *}$ \\
\hline LIABILITIES & $.836^{\mathrm{kn}}$ & $.904^{n *}$ & $.970^{\mathrm{km}}$ & $.749^{*}$ & $.950^{\prime \prime}$ & $.921^{* *}$ & $.973^{\text {"* }}$ & $.243^{*}$ \\
\hline Current Liabilities & .579 & $.779^{\prime * *}$ & $.983^{* x}$ & .601 & $.908^{\prime \prime *}$ & $.763^{*}$ & $.945^{\mathrm{N}}$ & $.253^{x}$ \\
\hline Deferred Tax & $.947^{* *}$ & .485 & $.993^{\mathrm{kn}}$ & .604 & $.905^{\mathrm{k*}}$ & $.973^{\mathrm{kx}}$ & $.939^{\prime \prime \prime}$ & $.748^{* *}$ \\
\hline Long Term Liabilities & $.861^{\star *}$ & $.905^{\mathrm{kn}}$ & $.939^{\mathrm{kn}}$ & $.817^{\mathrm{*m}}$ & $.946^{n x}$ & $.902^{\mathrm{kx}}$ & $.958^{\mathrm{N}}$ & .174 \\
\hline $\begin{array}{l}{ }^{*} \text { Correlation is significa } \\
{ }^{*} \text { Correlation is significar } \\
\text { a. Cannot be computed }\end{array}$ & $\begin{array}{l}\text { the } .01 \mathrm{le} \\
\text { he } .05 \mathrm{lev} \\
\text { ause at lea }\end{array}$ & 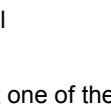 & (n) & nstant. & & & & \\
\hline
\end{tabular}

Source: Author

From the close correlation that can be seen in the individual company's regression lines, it could be deduced that the share prices are explained to a large degree by the debt levels in the various companies, but from the large differences in slope of these regression lines it is concluded that debt cannot be seen as a primary driving factor for share prices in general; therefore, in order to explain share price movement, other factors should also be considered.

Equity has also shown a high level of correlation for all the companies, but with a higher level of correlation for the combined data than with the other variables. This is to be expected due to the fact that the equity is the 
company's representation of the value of the combined shares, and this is a confirmation that the share price, being the market's interpretation of equity value, follows the financial statements' or directors' indication of equity value.

Figure 2

Total debt correlation to closing share prices of PLSs

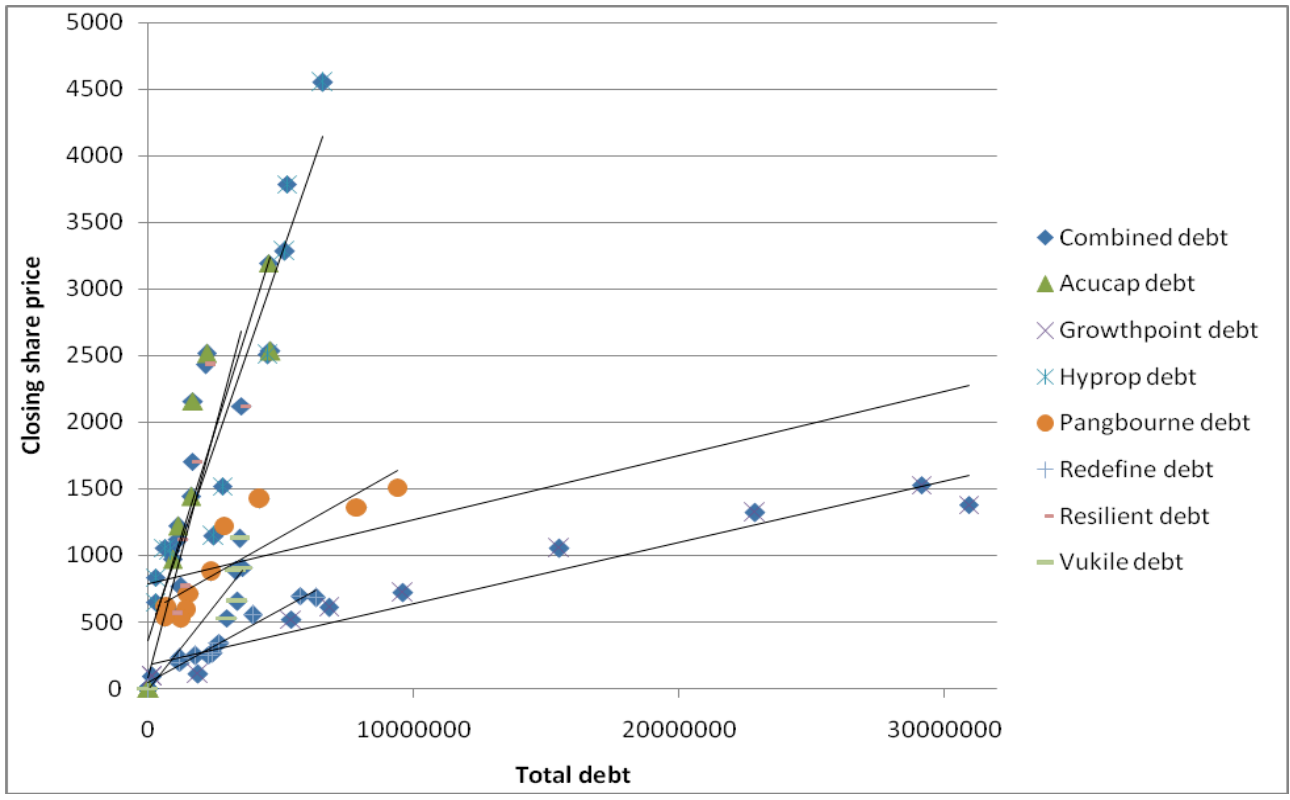

Source: Author

Table 4 provides the closing share price as it correlates with the income statement items. A fair degree of consistent high correlation for various items is evident, but again there are a number of variables that correlate well for company specific data, but have a substantial lower correlation for combined data. This is especially visible for the turnover figures, and is represented in Figure 3.

Table 4

Income statement correlation to closing share prices of PLSs

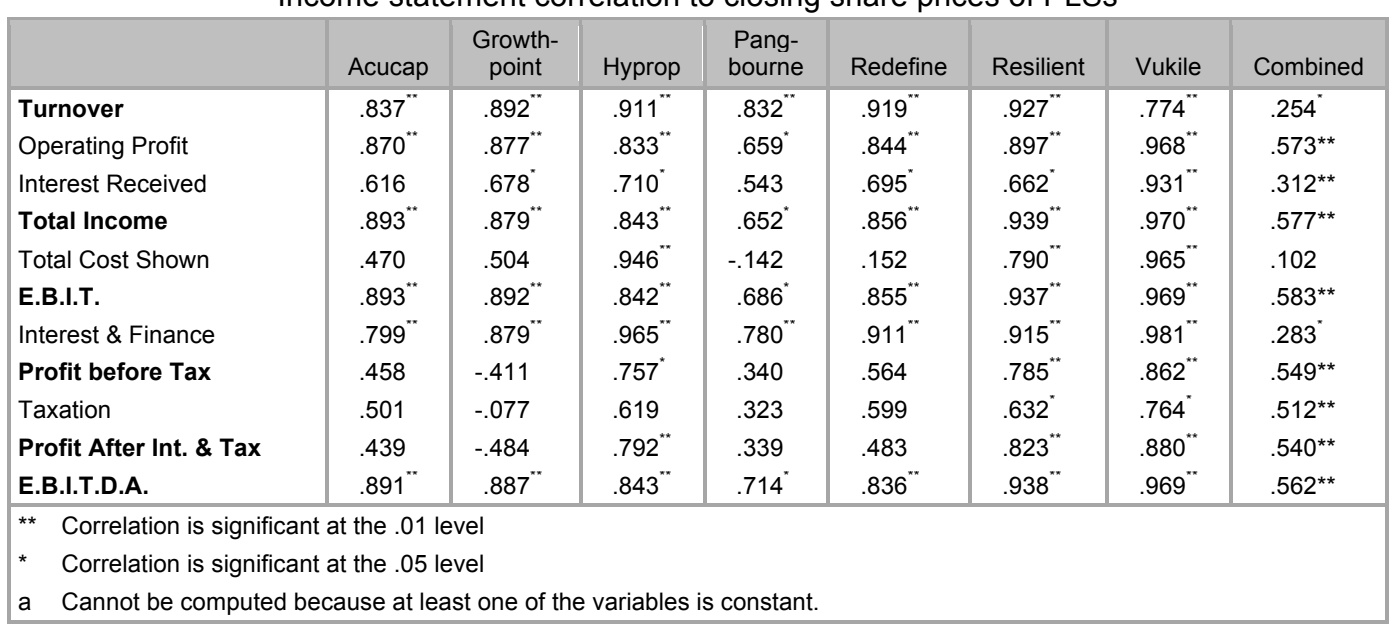




\section{Figure 3}

Turnover correlation to closing share prices of PLSs

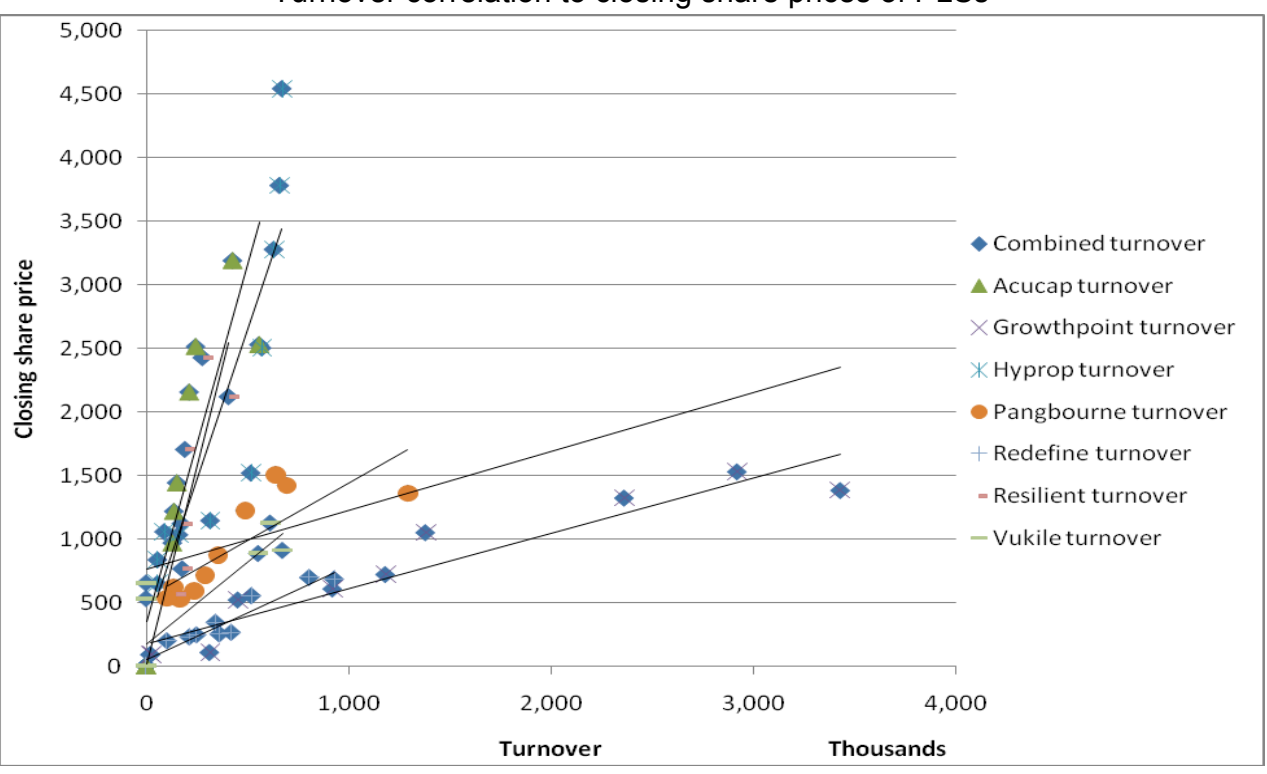

Source: Author

It is noticeable that the profit items are having higher correlations than the items that include expenses. Operating profit, earnings before interest and tax (E.B.I.T.). and earnings before interest, tax, depreciation and amortisation (E.B.I.T.D.A.) are the highest correlating variables for the combined data, with equally high correlations for the individual companies.
This would suggest a high consideration for the returns of the companies in share price determination.

Tables 5 and 6 consider the correlation to the various companies' balance sheets and income statements respectively to the average share prices for the year opposed to the closing share price as seen in tables 3 and 4 .

Table 5

Balance sheet correlation to weighted average share price of PLSs

\begin{tabular}{|c|c|c|c|c|c|c|c|c|}
\hline & Acucap & $\begin{array}{l}\text { Growth- } \\
\text { point }\end{array}$ & Hyprop & $\begin{array}{l}\text { Pang- } \\
\text { bourne }\end{array}$ & Redefine & Resilient & Vukile & Combined \\
\hline ASSETS & $.918^{\mathrm{x}}$ & $.973^{\mathrm{kx}}$ & $.984^{n *}$ & $.871^{m *}$ & $.973^{* n}$ & $.928^{k *}$ & $.979^{\mathrm{x}}$ & $.409^{\star *}$ \\
\hline Fixed Assets & $.930^{* *}$ & $.974^{* *}$ & $.968 *$ & $.833^{* *}$ & $.941^{* *}$ & $.908^{* *}$ & $.978^{* *}$ & $.379^{\star *}$ \\
\hline Current Assets & .401 & $.660^{*}$ & $.717^{*}$ & $.841^{\prime \prime \prime}$ & $.870^{\mathrm{kx}}$ & $.695^{*}$ & $.808^{\mathrm{kx}}$ & $.272^{*}$ \\
\hline Non Current Assets & $.650^{*}$ & $.685^{*}$ & $.878^{\mathrm{km}}$ & .267 & .524 &.$^{\mathrm{a}}$ & $.693^{*}$ & $.374^{* *}$ \\
\hline Intangible Assets & .338 & $.678^{*}$ &.$^{a}$ & $.665^{*}$ &.$^{a}$ & .469 & $.930 "$ & .100 \\
\hline EQUITY & $.898^{\mathrm{kx}}$ & $.700^{*}$ & $.992^{* *}$ & $.890^{\mathrm{n*}}$ & $.944^{* *}$ & $.911^{* *}$ & $.963^{\mathrm{x}}$ & $.689^{\star *}$ \\
\hline Ordinary S.H. Interest & $.898^{\mathrm{x}}$ & $.700^{*}$ & $.978^{\text {"*x }}$ & $.870^{\mathrm{mm}}$ & $.944^{n *}$ & $.909^{k *}$ & $.957^{\mathrm{x}}$ & $.651^{\star *}$ \\
\hline Outside S.H. Interest &.$^{a}$ &.$^{\mathrm{a}}$ & .629 & .532 & .524 &.$^{\mathrm{a}}$ & .135 & $.553^{\star \star}$ \\
\hline LIABILITIES & $.913^{\mathrm{kx}}$ & $.971^{\prime *}$ & $.959^{\mathrm{kx}}$ & $.872^{n *}$ & $.980^{* *}$ & $.922^{\prime *}$ & $.958^{\mathrm{w}}$ & $.291^{*}$ \\
\hline Current Liabilities & $.736^{*}$ & $.803^{\mathrm{kx}}$ & $.976^{\mathrm{kx}}$ & $.766^{\mathrm{m*}}$ & $.936^{\mathrm{kx}}$ & $.771^{* *}$ & $.902^{\mathrm{w}}$ & $.319^{* *}$ \\
\hline Deferred Tax & $.948^{\mathrm{kx}}$ & $.679^{*}$ & $.993^{* * *}$ & $.755^{*}$ & $.927^{* *}$ & $.980^{\mathrm{k*}}$ & $.952^{\mathrm{*}}$ & $.766^{* *}$ \\
\hline Long Term Liabilities & $.913^{\mathrm{kx}}$ & $.974 \times$ & $.924^{* *}$ & $.913^{n *}$ & $.976^{* *}$ & $.900 "$ & $.942^{\mathrm{x}}$ & .219 \\
\hline $\begin{array}{ll}\text { ** } & \text { Correlation is signi } \\
\text { * } & \text { Correlation is signi } \\
\text { a } & \text { Cannot be comput }\end{array}$ & $\begin{array}{l}\text { it the } .01 \text { I } \\
\text { t the } .05 \text { I } \\
\text { ause at le }\end{array}$ & $\begin{array}{l}\text { vel } \\
\text { vel } \\
\text { st one of th }\end{array}$ & variables & constant. & & & & \\
\hline
\end{tabular}




\section{Table 6}

Income statement correlation to weighted average share prices of PLSs

\begin{tabular}{|c|c|c|c|c|c|c|c|c|}
\hline & Acucap & $\begin{array}{l}\text { Growth- } \\
\text { point }\end{array}$ & Hyprop & $\begin{array}{l}\text { Pang- } \\
\text { bourne }\end{array}$ & Redefine & Resilient & Vukile & Combined \\
\hline Turnover & $.892^{\mathrm{xx}}$ & $.952^{\mathrm{k*}}$ & $.890^{\mathrm{n*}}$ & $.818^{n *}$ & $.953^{\mathrm{kx}}$ & $.924^{* *}$ & $.843^{\mathrm{xx}}$ & $.298^{*}$ \\
\hline Operating Profit & $.836^{* *}$ & $.946^{\prime *}$ & $.814^{n *}$ & $.815^{n *}$ & $.779^{\mathrm{kx}}$ & $.886^{* *}$ & $.911^{x \times}$ & $.594^{\star *}$ \\
\hline Interest Received & $.644^{*}$ & $.715^{\star}$ & $.743^{*}$ & $.732^{*}$ & $.761^{*}$ & $.676^{*}$ & $.929^{x \times}$ & $.364^{\star *}$ \\
\hline Total Income & $.864^{* *}$ & $.947^{\prime *}$ & $.825^{\mathrm{km}}$ & $.812^{n *}$ & $.793^{\mathrm{kn}}$ & $.931^{* *}$ & $.913^{* \prime}$ & $.601^{* *}$ \\
\hline Total Cost Shown & .428 & $.686^{*}$ & $.935^{\mathrm{nn}}$ & -.098 & 199 & $.788^{* *}$ & $.986^{* *}$ & .127 \\
\hline E.B.I.T. & $.864^{\mathrm{x}}$ & $.953^{k *}$ & $.824^{* *}$ & $.845^{\mathrm{km}}$ & $.792^{* *}$ & $.929^{* *}$ & $.911^{x \times}$ & $.605^{\star *}$ \\
\hline Interest \& Finance & $.849^{* x}$ & $.947^{m *}$ & $.951^{\mathrm{N*}}$ & $.824^{n *}$ & $.954^{n *}$ & $.915^{* *}$ & $.976^{\mathrm{Nx}}$ & $.330^{* *}$ \\
\hline Profit before Tax & .368 & -.599 & $.739^{*}$ & .513 & .456 & $.774^{* *}$ & $.759^{*}$ & $.533^{\star *}$ \\
\hline Taxation & .398 & -.156 & .606 & .450 & .575 & .615 & .631 & $.496^{\star \star}$ \\
\hline Profit After Int. \& Tax & .356 & $-.688^{*}$ & $.772^{\prime *}$ & .524 & .360 & $.814^{n *}$ & $.789^{* *}$ & $.525^{\star *}$ \\
\hline E.B.I.T.D.A. & $.863^{* *}$ & $.955^{\prime *}$ & $.825^{\mathrm{k*}}$ & $.865^{n *}$ & $.773^{* *}$ & $.930^{\circ *}$ & $.911^{\mathrm{N}}$ & $.584^{* *}$ \\
\hline $\begin{array}{ll}\text { ** } & \text { Correlation is signifi } \\
\text { * } & \text { Correlation is signifi } \\
\text { a } & \text { Cannot be compute }\end{array}$ & $\begin{array}{l}\text { at the } .01 \mathrm{le} \\
\text { at the } .05 \mathrm{le} \\
\text { sause at lea }\end{array}$ & $\begin{array}{l}\text { iel } \\
\text { iel } \\
\text { t one of the }\end{array}$ & variables & constant. & & & & \\
\hline
\end{tabular}

Source: Authors

The financial statement items show more consistent correlations with the weighted average share prices than with the correlation with the closing price of the company shares. It is also notable that the correlations are higher also for the combined data for the average share price than with the closing price. The items showing best correlations are however similar to those identified for the closing share price, and the tendencies are also similar, for the same reasons as mentioned earlier. The correlations however seem to provide a slightly stronger explanation on share prices than did the accounting ratios. This could however not be stated conclusively.

As the share price of a company is only the price paid for a single share, but the financial statements consider the company as a whole (i.e. all the issued shares), consideration should also be given to the market capitalisation of the companies, in other words, the latest share price multiplied by the number of shares in issue. Although this is not strictly speaking the correlation of the share price with financial statements, it is the total value of the company as per the daily share price movement.

Due to the higher correlation of weighted average share prices with all different variables, it is expected that the weighted average market capitalisation (weighted average share price multiplied by weighted average number of shares) will also provide higher correlations with the different variables in question than the closing market capitalisation. This was tested and confirmed to be the situation, but is not shown here. Subsequently, only the weighted average market capitalisation of each company is considered, to the extent that it correlates with the financial statements of the company. The results of this are shown on tables 7 and 8 .

The correlation of the weighted average market capitalisation with the balance sheet and income statement of the respective company shows levels of consistent correlation that are substantially higher than the correlation with the weighted average share prices. What is however of interest is that in these two tables, the variables that had $\mathrm{t}$ he largest discrepancies between individual company and combined data, are now showing the highest correlations for the combined data, which are also substantially higher than any correlations found in the test for correlation with singles share prices, or accounting ratios. 


\section{Table 7}

Balance sheet correlation to weighted average market capitalisation of PLSs

\begin{tabular}{|c|c|c|c|c|c|c|c|c|}
\hline & Acucap & $\begin{array}{l}\text { Growth- } \\
\text { point }\end{array}$ & Hyprop & $\begin{array}{l}\text { Pang- } \\
\text { bourne }\end{array}$ & Redefine & Resilient & Vukile & Combined \\
\hline ASSETS & $.997^{n *}$ & $.993^{\mathrm{xx}}$ & $.984^{\star *}$ & $.969^{k *}$ & $.996^{\mathrm{nN}}$ & $.989^{k *}$ & $.962^{* *}$ & $.983^{* *}$ \\
\hline Fixed Assets & $.996^{* n}$ & $.992^{\mathrm{*}}$ & $.968^{\mathrm{*x}}$ & $.950^{n *}$ & $.995^{\mathrm{n}}$ & $.982^{n *}$ & $.960^{\mathrm{*x}}$ & $.976^{\star \star}$ \\
\hline Current Assets & .357 & $.801^{\star x}$ & $.684^{*}$ & $.936^{n * *}$ & $.957^{\mathrm{n*}}$ & $.782^{n *}$ & $.793^{n *}$ & $.598^{\star *}$ \\
\hline Non Current Assets & $.879^{* *}$ & $.749^{*}$ & $.867^{* *}$ & .104 & $.670^{*}$ &.$^{a}$ & $.741^{*}$ & $.743^{\star *}$ \\
\hline Intangible Assets & .573 & $.839^{* *}$ &.$^{a}$ & .489 &.$^{\mathrm{a}}$ & $.696^{*}$ & $.934^{* *}$ & $.776^{\star \star}$ \\
\hline EQUITY & $.992^{* * *}$ & $.855^{\mathrm{kx}}$ & $.994^{\mathrm{*x}}$ & $.977^{* *}$ & $.994^{* * *}$ & $.992^{* *}$ & $.980 "$ & $.437^{\star *}$ \\
\hline Ordinary S.H. Interest & $.992^{k *}$ & $.855^{\alpha *}$ & $.993^{* *}$ & $.973^{* *}$ & $.994^{* * *}$ & $.992^{* *}$ & $.976^{m *}$ & $.445^{\star *}$ \\
\hline Outside S.H. Interest & $\stackrel{a}{.}$ & $\stackrel{a}{.}$ & .568 & .541 & $.670^{*}$ & $\stackrel{a}{.}$ & .047 & .119 \\
\hline LIABILITIES & $.986^{\prime \prime *}$ & $.994^{* *}$ & $.948^{* \times}$ & $.965^{\prime \prime *}$ & $.980^{\mathrm{m*}}$ & $.962^{n *}$ & $.932^{* *}$ & $.970^{\star \star}$ \\
\hline Current Liabilities & $.885^{\mathrm{kn}}$ & $.822^{\mathrm{x*}}$ & $.982^{\mathrm{m}}$ & $.893^{\mathrm{km}}$ & $.982^{\mathrm{kn}}$ & $.911^{\prime \prime}$ & $.887^{m *}$ & $.794^{\star *}$ \\
\hline Deferred Tax & $.913^{\mathrm{kn}}$ & $.838^{\mathrm{N*}}$ & $.989^{\prime *}$ & $.906^{\prime *}$ & $.984^{\mathrm{N*}}$ & $.973^{\mathrm{kn}}$ & $.971^{\prime \prime}$ & $.429^{\star *}$ \\
\hline Long Term Liabilities & $.967^{* \pi}$ & $.994^{\mathrm{*}}$ & $.921^{\star *}$ & $.986^{\mathrm{kn}}$ & $.961^{\mathrm{N}}$ & $.926^{\mathrm{kn}}$ & $.909^{\mathrm{x}}$ & $.953^{* *}$ \\
\hline $\begin{array}{ll}* & \text { Correlation is signi } \\
\text { * } & \text { Correlation is signi } \\
\text { a } & \text { Cannot be comput }\end{array}$ & $\begin{array}{l}\text { at the } .01 \mathrm{I} \\
\text { at the } .05 \mathrm{I} \\
\text { ause at le }\end{array}$ & $\begin{array}{l}\text { vel } \\
\text { vel } \\
\text { t one of } t\end{array}$ & ariable & constan & & & & \\
\hline
\end{tabular}

Source: Authors

Table 8

Income statement correlation to weighted average market capitalisation of PLSs

\begin{tabular}{|c|c|c|c|c|c|c|c|c|}
\hline & Acucap & $\begin{array}{l}\text { Growth- } \\
\text { point }\end{array}$ & Hyprop & $\begin{array}{l}\text { Pang- } \\
\text { bourne }\end{array}$ & Redefine & Resilient & Vukile & Combined \\
\hline Turnover & $.968^{* *}$ & $.991^{* *}$ & $.884^{* *}$ & $.927^{* *}$ & $.966^{\mathrm{k*}}$ & $.937^{\mathrm{k*}}$ & $.877^{\alpha *}$ & $.965^{\star *}$ \\
\hline Operating Profit & $.688^{*}$ & $.987^{* *}$ & $.770^{* *}$ & $.792^{* *}$ & $.682^{*}$ & $.737^{*}$ & $.878^{* *}$ & $.764^{\star *}$ \\
\hline Interest Received & $.831^{\prime *}$ & $.639^{\prime \prime}$ & $.742^{*}$ & $.837^{* *}$ & $.879^{\prime \prime m}$ & $.858^{\prime *}$ & $.935^{k *}$ & $.707^{\star \star}$ \\
\hline Total Income & $.744^{*}$ & $.981^{* *}$ & $.782^{* *}$ & $.802^{\mathrm{k}}$ & $.700^{*}$ & $.812^{\prime *}$ & $.880^{k *}$ & $.782^{\star *}$ \\
\hline Total Cost Shown & .325 & $.850^{k *}$ & $.936^{* *}$ & .073 & .176 & $.758^{*}$ & $.980^{k *}$ & $.475^{\star *}$ \\
\hline E.B.I.T. & $.745^{*}$ & $.979^{k *}$ & $.780^{* *}$ & $.812^{\mathrm{*}}$ & $.699^{\prime \prime}$ & $.810^{k *}$ & $.878^{\mathrm{kx}}$ & $.772^{\star *}$ \\
\hline Interest \& Finance & $.950 "$ & $.982^{n *}$ & $.961^{* *}$ & $.957^{w *}$ & $.992^{\prime \prime *}$ & $.960^{\prime *}$ & $.961^{* *}$ & $.969^{\star *}$ \\
\hline Profit before Tax & .099 & $-.793^{n *}$ & $.684^{*}$ & .379 & .311 & .587 & $.712^{*}$ & .094 \\
\hline Taxation & .139 & -.422 & .536 & .257 & .507 & .381 & .596 & .109 \\
\hline Profit After Int. \& Tax & .083 & $-.827^{m *}$ & $.725^{*}$ & .411 & .207 & $.646^{*}$ & $.739^{*}$ & .085 \\
\hline E.B.I.T.D.A. & $.742^{\prime \prime}$ & $.983^{* *}$ & $.781^{m *}$ & $.825^{\prime *}$ & $.702^{\prime \prime}$ & $.810^{\prime *}$ & $.878^{\prime *}$ & $.764^{\star *}$ \\
\hline $\begin{array}{ll}\text { ** } & \text { Correlation is signi } \\
* & \text { Correlation is signi } \\
\text { a } & \text { Cannot be comput }\end{array}$ & $\begin{array}{l}t \text { at the } .01 \\
\text { t at the } .05 \\
\text { cause at le }\end{array}$ & $\begin{array}{l}\text { evel } \\
\text { evel } \\
\text { ast one of } t\end{array}$ & e variable & is constan & & & & \\
\hline
\end{tabular}

Source: Authors

The variable with the highest correlation is total assets. This is indicated by Figure 4, where the similar slope in the regression lines for all the companies can be seen. This is an indication that shareholders take a combined look at the company as a whole when making individual share price decisions. Shareholders are therefore reacting on the actions of all other investors, and are comparing the sum of all shares to the value of the company's assets. This furthermore is an indication that the total sum of all shares as seen by market activity is in line with the market's expectations of the total assets of the company. An interesting deduction is that the correlations on the combined data for the balance sheet are higher than the correlations in the income statement; therefore it seems as if investors are putting emphasis on the assets, and they are purchasing a share in a portfolio of properties for the actual return that they will receive. 


\section{Figure 4}

Total assets correlation to weighted average market capitalisation of PLSs

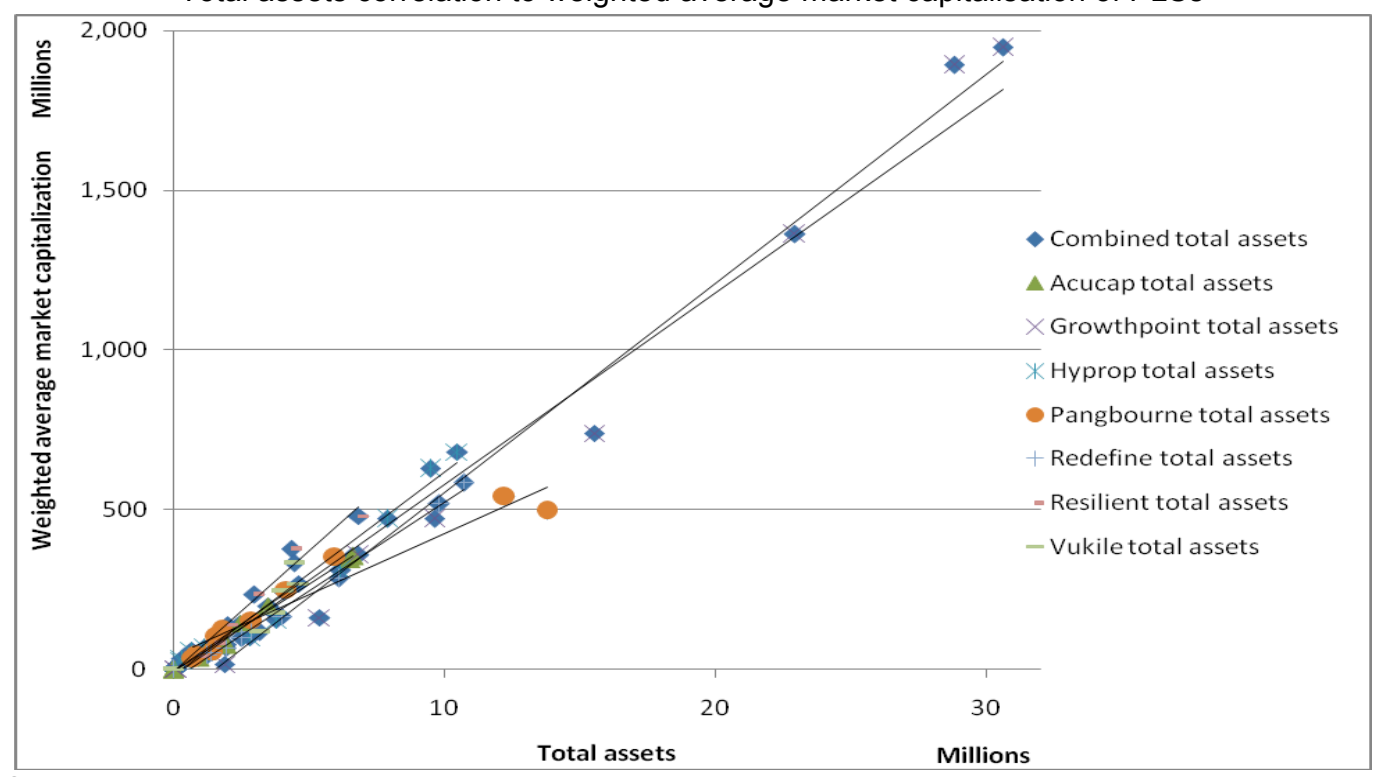

Source: Authors

In summary, the correlation of normal financial statement items with the share prices of the PLS companies seems to be slightly better than the correlation of the accounting ratios and share prices of these companies. There is also a slightly higher correlation between the weighted average share price for the year and the financial statement items, than between the closing share price and the financial statements, indicating that investors are considering the operations of the company in the long term, and the share price that fluctuates daily is doing so within the boundaries that are created by the essentials of the company, being the variables on the financial statements. This confirms the presumption that PLS companies are unique in the sense that the balance sheet items, or assets in themselves are the investment, rather than the operations of the company, as found with other JSE listed companies.

The correlation of the weighted average market capitalisation with the financial statement items is, however, of more reliance than the individual share prices. The accounting ratios provide information on the company's performance, but as ratios they provide information that is significant for individual shares, while the financial statements provide information on the company as a whole, and should therefore be considered in relation to the market capitalisation. The longterm market capitalisation of these companies is therefore a good indication of how investors are viewing these companies, and with the high correlation with total assets, is also a good indication of the values of the properties underlying the balance sheet, hence also the direct property market.

\section{5 \\ Correlation of share price with the JSE}

In the previous section it was indicated that a high level of correlation exist between the financial statements and the market capitalisation of the shares of such a company. It is also evident that the correlation exists in a similar way for all companies, and that the total market capitalisation could be accurately predicted by considering the balance sheet of the companies. This ultimately is influenced by investors in the price they are prepared to pay for the shares, taking into consideration the number of shares that are issued. Equally, the 
value of the underlying assets could be predicted by considering the going share price, multiplied by the total number of shares issued.

If, however, we again consider Figure 1, there is much fluctuation in the share price, and subsequently in the market capitalisation of the shares between year-end dates, when information on company performance becomes available to shareholders and prospective investors. It is presumed that shareholders cannot have sufficient information on the individual companies that could drive them to make buy-and-sell decisions on a daily basis that could cause such high fluctuations in the market. In this section the fluctuations in the share prices will be considered in order to resolve this question.

When the share prices of the different companies are viewed as per Figure 1 it can be seen that the prices are moving in a similar way. It is therefore presumed that the cause of the fluctuations is affecting the companies alike, and should therefore be of an external nature, rather than originating from variables within the company itself.

As part of the PLS sector, which in turn forms part of the financial sector and the overall JSE, the share prices are compared to various indexes in order to explain the fluctuations. The indexes under consideration are the following:

- the J253 SA Property Index;

- the J256 PLS Index;

- the J203 All Share Index; and

- the J580 Finacials Index.

If this is correlated with the individual share prices, the results are as indicated in Table 9.

Table 9

JSE indices correlation to weighted average share prices of PLSs

\begin{tabular}{|c|c|c|c|c|c|c|c|c|}
\hline & Acucap & $\begin{array}{l}\text { Growth- } \\
\text { point }\end{array}$ & Hyprop & $\begin{array}{l}\text { Pang- } \\
\text { bourne }\end{array}$ & Redefine & Resilient & Vukile & Combined \\
\hline J253 SA Property & $.989^{\mathrm{kx}}$ & $.987^{\prime \prime \prime}$ & $.991^{* *}$ & $.982^{\mathrm{kx}}$ & $.991^{\star *}$ & $.965^{n *}$ & $.980^{\mathrm{*}}$ & $.9966^{* *}$ \\
\hline J256 PLS & $.990^{\mathrm{k \prime}}$ & $.995^{\mathrm{kx}}$ & $.997^{\mathrm{N}}$ & $.988^{\mathrm{xx}}$ & $.991^{\prime *}$ & $.990^{\mathrm{kn}}$ & $.976^{* x}$ & $.998^{\mathrm{kx}}$ \\
\hline J203 All Share & $.931^{* *}$ & .928 & $.944^{* *}$ & $.929^{\prime *}$ & $.941^{\mathrm{m}}$ & $.931^{* *}$ & $.909^{* *}$ & $.936^{\prime *}$ \\
\hline J580 Financials & $.938^{* *}$ & $.926^{\mathrm{m}}$ & $.935^{* *}$ & $.941^{\pi *}$ & $.938^{* *}$ & $.858^{\mathrm{kn}}$ & $.866^{* *}$ & $.927^{\mathrm{xx}}$ \\
\hline \multicolumn{9}{|c|}{$\begin{array}{l}\text { ** Correlation is significant at the } .01 \text { level } \\
\text { * Correlation is significant at the } .05 \text { level } \\
\text { a Cannot be computed because at least or }\end{array}$} \\
\hline
\end{tabular}

Source: Authors

The high correlation with the J253 and $\mathrm{J} 256$ is expected, as the companies that are considered form a major part of these indexes. As said earlier, the seven companies under consideration make up 90 per cent of the PLS sector, and therefore the index is just a reflection of the sum of these companies. Therefore the combined correlation between the companies and the index should be close. It could be argued that this is also the case with the Financial and All share indexes, but if it is taken into consideration that the PLS sector makes up only 4.1 per cent of the financial sector and 0.8 per cent of the JSE, a change in a single company, or even in the PLS sector as a whole, will not have any significant effect on the two respective indexes. It is therefore stated that the influence is the other way round, with fluctuations in the share price of individual PLS companies being influenced by general JSE sentiment, and not by anything caused by company operations. This confirms that irrational behaviour of investors is equally applicable to property shares as to other listed shares, and provides the opportunity to further investigate behavioural finance theory on property investment. If the principles of behavioural finance could be applied to property shares, a lot could be learnt from the listed property sector which, due to the correlations that were seen earlier in this paper between property shares and the underlying assets, could be applied to direct property investment as well. 


\section{6}

\section{Correlation of share price with economy}

In the previous section it was shown that the fluctuations in the share prices of PLS companies are caused largely due to the JSE sentiment, in other words, factors affecting the JSE as a whole rather than the operations of the companies itself, although the long-term growth in share prices could be determined by the growth in assets, divided by the number of shares issued. It should however be asked, what is driving the growth of the PLS companies in the long term? Why are PLS companies growing and what causes the longterm increase in balance sheet and therefore share prices? If the driving forces in the longterm growth can be identified, it is also possible to determine the extent that these companies are likely to grow in the long term, and what fundamentals to address, or opportunities to explore in order to excel. It furthermore could provide a link to predict market capitalisation movement within a specific framework, from where the value of the underlying assets could be predicted.

With these questions, the share prices, market capitalisation and balance sheets of the

Table 10

Economic factors correlation to closing share prices of PLSs

\begin{tabular}{|c|c|c|c|c|c|c|c|c|}
\hline & Acucap & $\begin{array}{l}\text { Growth- } \\
\text { point }\end{array}$ & Hyprop & $\begin{array}{l}\text { Pang- } \\
\text { bourne }\end{array}$ & Redefine & Resilient & Vukile & Combined \\
\hline $\begin{array}{l}\text { Total employment in the } \\
\text { private sector }\end{array}$ & $.869^{* *}$ & $.883^{* * *}$ & $.885^{* *}$ & $.879^{* *}$ & $.860^{* *}$ & $.945^{* *}$ & $.827^{\star * *}$ & $.893^{* *}$ \\
\hline $\begin{array}{l}\text { Total employment in the } \\
\text { public sector }\end{array}$ & $.859^{* *}$ & $.888^{* *}$ & $.898^{* *}$ & $.856^{* *}$ & $.873^{* *}$ & $.930^{* *}$ & $.748^{* *}$ & $.891^{* *}$ \\
\hline $\begin{array}{l}\text { Total employment in the Non- } \\
\text { agricultural sector }\end{array}$ & $.881^{* *}$ & $.897^{* \star *}$ & $.900^{* *}$ & $.890^{* *}$ & $.874^{* *}$ & $.947^{* *}$ & $.822^{* *}$ & $.906^{* *}$ \\
\hline $\begin{array}{l}\text { Disposable income of } \\
\text { households }\end{array}$ & $.863^{* *}$ & $.893^{* * *}$ & $.898^{* *}$ & $869^{* *}$ & $.867^{* *}$ & $.912^{* *}$ & $.700^{* *}$ & $.897^{* *}$ \\
\hline $\begin{array}{l}\text { Ratio of saving by house- } \\
\text { holds to disposable income }\end{array}$ & $-.920^{* *}$ & $-.915^{* *}$ & $-.929^{* *}$ & $-.910^{* *}$ & $-.911^{* *}$ & $-.888^{* *}$ & $-.820^{* *}$ & $-.927^{* *}$ \\
\hline $\begin{array}{l}\text { Total national government } \\
\text { debt as } \% \text { of GDP }\end{array}$ & $-.840^{* *}$ & $-.878^{* *}$ & $-.882^{* *}$ & $-.851^{* *}$ & $-.849^{* *}$ & $-.901^{* *}$ & $-.719^{* *}$ & $-.880^{* *}$ \\
\hline $\begin{array}{l}\text { National government revenue } \\
\text { as } \% \text { of GDP }\end{array}$ & $.732^{* *}$ & $.719^{* * *}$ & $.725^{* *}$ & $.721^{* *}$ & $.721^{* *}$ & $.634^{* *}$ & $.522^{* * *}$ & $.720^{* *}$ \\
\hline $\begin{array}{l}\text { National government } \\
\text { expenditure as \% of GDP }\end{array}$ & $.326^{* *}$ & $.318^{* * *}$ & $.332^{* *}$ & $.305^{* *}$ & $.298^{* *}$ & $.331^{* *}$ & $.200^{* * *}$ & $.325^{* *}$ \\
\hline $\begin{array}{l}\text { Gross domestic product at } \\
\text { market prices (GDP) }\end{array}$ & $.852^{* *}$ & $.884^{* * *}$ & $.891^{* *}$ & $.858^{* *}$ & $.862^{* *}$ & $.909^{* *}$ & $.686^{* *}$ & $.888^{* *}$ \\
\hline $\begin{array}{l}\text { Gross value added at basic } \\
\text { prices of construction (GDP) }\end{array}$ & $.824^{* *}$ & $.858^{* *}$ & $.861^{* \star}$ & $.833^{* *}$ & $.828^{* *}$ & $.894^{* *}$ & $.681^{* \star}$ & $.861^{* *}$ \\
\hline Repo & $-.296^{\prime \prime \prime}$ & $-.203^{\mathrm{xw}}$ & $-.227^{* m}$ & $-.297^{* *}$ & $-.195^{* x}$ & -.002 & $.440^{\mathrm{kx}}$ & $-.258^{n *}$ \\
\hline \multicolumn{9}{|c|}{$\begin{array}{l}\text { ** Correlation is significant at the } .01 \text { level } \\
\text { * Correlation is significant at the } .05 \text { level } \\
\text { a Cannot be computed because at least or }\end{array}$} \\
\hline
\end{tabular}

Source: Authors

case study are compared to various macroeconomic variables. The main drivers of the economy that are tested are the following:

- Total employment in the private sector

- Total employment in the public sector

- Total employment in the non-agricultural sector

- Disposable income of households

- Ratio of saving by households to disposable income of households
- Total national government debt as a percentage of GDP

- National government revenue as a percentage of GDP

- National government expenditure as a percentage of GDP

- Gross domestic product at market prices (GDP)

- Gross value added at basic prices of construction (contractors) (GDP)

- Repo rate 
The correlation of these variables with the individual companies' share prices, number of shares and market capitalisation is indicated in Tables 10 to 12 .

Table 11

Economic factors correlation to number of shares of PLSs

\begin{tabular}{|c|c|c|c|c|c|c|c|c|}
\hline & Acucap & $\begin{array}{l}\text { Growth- } \\
\text { point }\end{array}$ & Hyprop & $\begin{array}{l}\text { Pang- } \\
\text { bourne }\end{array}$ & Redefine & Resilient & Vukile & Combined \\
\hline $\begin{array}{l}\text { Total employment in the private } \\
\text { sector }\end{array}$ & $.843^{* *}$ & $.847^{* *}$ & $.898^{* *}$ & $.753^{* *}$ & $.570^{* *}$ & $.863^{* *}$ & $.811^{* *}$ & $.817^{* *}$ \\
\hline $\begin{array}{l}\text { Total employment in the Public } \\
\text { sector }\end{array}$ & $.981^{* *}$ & $.948^{* *}$ & $.901^{* *}$ & $.905^{* *}$ & $670^{* *}$ & $.940^{* *}$ & $.745^{* *}$ & $.910^{* *}$ \\
\hline $\begin{array}{l}\text { Total employment in the Non- } \\
\text { agricultural sector }\end{array}$ & $.869^{* *}$ & $.869^{* *}$ & $.911^{* *}$ & $.779^{* *}$ & $.588^{* *}$ & $.876^{* *}$ & $.807^{* *}$ & $.840^{* *}$ \\
\hline Disposable income of households & $.974 "$ & $.950^{\prime *}$ & $.935^{\mathrm{k*}}$ & $.919^{\mathrm{n*}}$ & $.674^{n *}$ & $.955^{\mathrm{*x}}$ & $.723^{\mathrm{w*}}$ & $.921^{\prime *}$ \\
\hline $\begin{array}{l}\text { Ratio of saving by house-holds to } \\
\text { disposable income }\end{array}$ & $-.798^{* *}$ & $-.803^{* *}$ & $-.889^{* *}$ & $-.629^{* * *}$ & $-.473^{* * *}$ & $-.696^{* *}$ & $-.719^{* *}$ & $-.745^{* *}$ \\
\hline $\begin{array}{l}\text { Total national government debt as } \\
\% \text { of GDP }\end{array}$ & $-.969^{* *}$ & $-.947^{* *}$ & $-.900^{* *}$ & $-.908^{* *}$ & $-.682^{* *}$ & $-.933^{* *}$ & $-.690^{* *}$ & $-.915^{* *}$ \\
\hline $\begin{array}{l}\text { National government revenue as } \\
\% \text { of GDP }\end{array}$ & $.507^{* * *}$ & $.532^{* *}$ & $.633^{* *}$ & $.285^{* *}$ & $.265^{* *}$ & $.352^{* *}$ & $.525^{* *}$ & $.469^{* *}$ \\
\hline $\begin{array}{l}\text { National government expenditure } \\
\text { as \% of GDP }\end{array}$ & $.335^{* *}$ & $.375^{* *}$ & $.337^{* *}$ & $.310^{* *}$ & $.302^{* *}$ & $.380^{* *}$ & $.179^{* *}$ & $.367^{* *}$ \\
\hline $\begin{array}{l}\text { Gross domestic product at market } \\
\text { prices (GDP) }\end{array}$ & $.987^{* * *}$ & $.960^{* * *}$ & $.928^{* * *}$ & $.933^{* *}$ & $.696^{* * *}$ & $.967^{* *}$ & $.708^{* *}$ & $.933^{* * *}$ \\
\hline $\begin{array}{l}\text { Gross value added at basic prices } \\
\text { of construction (GDP) }\end{array}$ & $.962^{* * *}$ & $.949^{* *}$ & $.904^{* *}$ & $.907^{* *}$ & $.681^{* *}$ & $.962^{* *}$ & $.698^{* *}$ & $.915^{* *}$ \\
\hline Repo & -.037 & $-.210^{\star *}$ & $-.343^{* *}$ & .015 & $-.250^{* * *}$ & -.022 & $.450^{* *}$ & $-.261^{* *}$ \\
\hline \multicolumn{9}{|c|}{$\begin{array}{l}\text { ** Correlation is significant at the } .01 \text { level } \\
* \quad \text { Correlation is significant at the } .05 \text { level } \\
\text { a Cannot be computed because at least on }\end{array}$} \\
\hline
\end{tabular}

Source: Authors

Table 12

Economic factors correlation to market capitalisation of PLSs

\begin{tabular}{|c|c|c|c|c|c|c|c|c|}
\hline & Acucap & $\begin{array}{l}\text { Growth- } \\
\text { point }\end{array}$ & Hyprop & $\begin{array}{l}\text { Pang- } \\
\text { bourne }\end{array}$ & Redefine & Resilient & Vukile & Combined \\
\hline $\begin{array}{l}\text { Total employment in the private } \\
\text { sector }\end{array}$ & $.860^{* * *}$ & $.879^{* * *}$ & $.896^{* *}$ & $.843^{* *}$ & $.635^{* *}$ & $.909^{* *}$ & $.866^{* *}$ & $.864^{* * *}$ \\
\hline $\begin{array}{l}\text { Total employment in the Public } \\
\text { sector }\end{array}$ & $.970^{* * *}$ & $.970^{* * *}$ & $.941^{* *}$ & $.962^{* *}$ & $.740^{* * *}$ & $.965^{* *}$ & $.795^{* *}$ & $.957^{* * *}$ \\
\hline $\begin{array}{l}\text { Total employment in the Non- } \\
\text { agricultural sector }\end{array}$ & $.883^{* *}$ & $.901^{\star \star}$ & $.913^{* *}$ & $.867^{* *}$ & $.655^{* * *}$ & $.919^{* *}$ & $.862^{* *}$ & $.887^{* * *}$ \\
\hline Disposable income of households & $.955^{\mathrm{N*}}$ & $.962^{\mathrm{N*}}$ & $.940^{\prime *}$ & $.968^{\mathrm{N*}}$ & $.732^{\mathrm{kn}}$ & $.961^{* *}$ & $.750^{\mathrm{k}}$ & $.953^{\mathrm{kn}}$ \\
\hline $\begin{array}{l}\text { Ratio of saving by house-holds to } \\
\text { disposable income }\end{array}$ & $-.844^{* *}$ & $-.857^{* *}$ & $-.920^{* *}$ & $-.776^{* *}$ & $-.576^{* *}$ & $-.753^{* *}$ & $-.832^{* *}$ & $-.837^{* *}$ \\
\hline $\begin{array}{l}\text { Total national government debt as } \\
\% \text { of GDP }\end{array}$ & $-.954^{* *}$ & $-.962^{* *}$ & $-.923^{* *}$ & $-.956^{* *}$ & $-.736^{* *}$ & $-.961^{* *}$ & $-.765^{* *}$ & $-.947^{* *}$ \\
\hline $\begin{array}{l}\text { National government revenue as } \\
\% \text { of GDP }\end{array}$ & $.588^{* *}$ & $.596^{* * *}$ & $.695^{* *}$ & $.477^{* * *}$ & $.371^{* *}$ & $.445^{* *}$ & $.530^{* *}$ & $.577^{* *}$ \\
\hline $\begin{array}{l}\text { National government expenditure } \\
\text { as } \% \text { of GDP }\end{array}$ & $.337^{* *}$ & $.347^{* * *}$ & $.341^{* *}$ & $.349^{* *}$ & $.313^{* *}$ & $.373^{* *}$ & $209^{* *}$ & $.355^{* *}$ \\
\hline $\begin{array}{l}\text { Gross domestic product at market } \\
\text { prices (GDP) }\end{array}$ & $.966^{* *}$ & $.971^{* *}$ & $.939^{* *}$ & $.977^{* *}$ & $.752^{* * *}$ & $.974^{* *}$ & $.736^{* *}$ & $.962^{* * *}$ \\
\hline $\begin{array}{l}\text { Gross value added at basic prices } \\
\text { of construction (GDP) }\end{array}$ & $.938^{* * *}$ & $.946^{* *}$ & $.908^{* *}$ & $.951^{* *}$ & $.732^{* * *}$ & $.973^{* *}$ & $.731^{* *}$ & $.935^{* * *}$ \\
\hline Repo & $-.081^{* *}$ & $-.120^{* *}$ & $-.196^{* *}$ & $-.106^{\mathrm{kn}}$ & $-.230^{\prime \prime}$ & .041 & $.478^{\mathrm{kx}}$ & $-.167^{* *}$ \\
\hline
\end{tabular}


The correlations show various items that have high correlations with the share prices, number of shares and market capitalisation of the companies. It could be seen that the correlation of all the items with the number of shares issued and market capitalisation of Redefine is substantially lower than the other PLS companies.

Upon investigation it was revealed that Redefine had a substantial increase in market capitalisation during 2009 due to a merger with two other PLS companies, and it is therefore providing a distorted view of the real situation, as the financial information of the other funds prior to the merger is not taken into consideration.

The combined correlations are indicated in Table 13, from where it is possible to compare the correlations to each other.

Table 13

Most relevant economic correlations

\begin{tabular}{|c|c|c|c|}
\hline & Closing price & No of shares & Market cap \\
\hline Total employment in the private sector & $.893^{\star *}$ & $.817^{\star *}$ & $.864^{\star *}$ \\
\hline Total employment in the Public sector & $.891^{\star *}$ & $.910^{\star *}$ & $.957^{\star *}$ \\
\hline Total employment in the Non-agricultural sector & $.906^{\star *}$ & $.840^{* *}$ & $.887^{* *}$ \\
\hline Disposable income of households & $.897^{\star *}$ & $.921^{\star *}$ & $.953^{\star *}$ \\
\hline Ratio of saving by households to disposable income & $-.927^{\star *}$ & $-.745^{m *}$ & $-.837^{\star *}$ \\
\hline Total national government debt as $\%$ of GDP & $-.880^{\star *}$ & $-.915^{\star *}$ & $-.947^{* *}$ \\
\hline National government revenue as percentage of GDP & $.720 "$ & $.469^{\mathrm{m*}}$ & $.577^{\mathrm{m*}}$ \\
\hline National government expenditure as $\%$ of GDP & $.325^{\mathrm{kn}}$ & $.367^{m *}$ & $.355^{\mathrm{kn}}$ \\
\hline Gross domestic product at market prices (GDP) & $.888^{\star *}$ & $.933^{\star *}$ & $.962^{\star *}$ \\
\hline Gross value added at basic prices of construction (GDP) & $.861^{* *}$ & $.915^{\star *}$ & $.935^{\star *}$ \\
\hline Repo & $-.258^{* * *}$ & $-.261^{* *}$ & $-.167^{* *}$ \\
\hline \multicolumn{4}{|l|}{$\begin{array}{l}\text { ** Correlation is significant at the } .01 \text { level } \\
\text { * Correlation is significant at the } .05 \text { level } \\
\text { a Cannot be computed because at least or }\end{array}$} \\
\hline
\end{tabular}

Source: Authors

As shown in Table 13, it is evident that the highest correlations are with the market capitalisation of the PLS companies. Variables that are significant are those of the employment levels, which is not surprising, due to the fact that with higher employment come more requirements for place to work, and subsequently higher levels of property investment, being retail, commercial or industrial, and subsequently the increase in market share growth for property.

The highest correlation is, however, that of gross domestic product (GDP) as it correlates with market capitalisation. GDP growth is generally seen as one of the most important indicators of economic growth, and it would subsequently also influence the demand for property. With an increase in economic activity, firms are in more need of real estate space to provide manufacturing, goods and services. It is notable that GDP also correlates closely with the number of shares issued, being an indication of the expansion of the PLS companies, not taking into consideration the price level increases of the shares. Although not shown in the tables above, the three company variables were also tested against real GDP, and the results were that market capitalisation is correlating slightly lower at $0.957 * *$, and the number of shares issued is slightly higher at $0.967 * *$. This confirms that the company growth is determined by GDP growth, but the market capitalisation and GDP both include general price level increases, while number of shares issued is an indication of real growth in the company. This last statement could however be distorted by share splits, or combinations.

Another important measure is that of gross value added at basic prices of construction. A positive correlation is expected due to the fact that an increase in property demand would 
initiate construction. The growth in property investment, as seen in the increase in market capitalisation of property shares, drives the construction levels, and therefore this variable is not considered to be a driver of property investment, being direct or indirect, other than stock adjustment and subsequent influence on demand and supply equilibrium (DiPasquale et al., 1992), but is the dependent variable.

The correlation of disposable income of households with the market capitalisation of shares is also significant. The disposable income of households is expected to increase with an increase in GDP as per general macroeconomic theory (Case et al., 1999). The one explanation is therefore that both market capitalisation and disposable income are dependant variables on GDP. The second explanation would be that households are increasing investment with an increase in disposable income, causing an increase in investment levels also in the direct and indirect property markets.

Correlations that were found to be much less reliable are those of national government revenue as percentage of GDP, national government expenditure as percentage of GDP, and the repo rate.

The highest negative correlation is of total national government debt as percentage of GDP with market capitalisation. This indicates that the effective use of government debt is an important driver of the economy, and ultimately the property market. If government is increasing its debt levels more quickly than the expansion of the GDP, it is destroying value and therefore the total market value levels of property are diminishing. This might be due to money that flows towards government debt rather than funding economic growth.

Another notable correlation is that of the ratio of savings by households with disposable income of households that shows significant negative correlations with the share prices of the PLS companies. This specific economic variable correlates even higher with the allshare index at $-0.942 * *$. GDP consists of household consumption, investment spending by firms, government expenditure and net exports, therefore an increase in household consumption would increase GDP. Over the past 20 years disposable income decreased from an average level of approximately 65 per cent to approximately 62 per cent of GDP. Although it is a negative trend, it does not appear to be drastic. If it is considered that disposable income consists of consumption by households and savings, it is deduced that if disposable income is stable, an increase in consumption spending by households should be funded from savings. This has the effect of an increase in GDP, which is explained earlier to cause an increase in direct and indirect real estate investment prices, at the cost of reduced savings. Therefore, although this negative correlation is evident from the case study, it is not an occurrence that would always exist, and is not to be seen as a reliable indicator of performance of shares, specifically in the property sector. The situation depicted here is actually of people that are saving less in order to risk their savings in higher risk / higher return investments, such as the stock market, or just consuming more at the cost of savings, which does increase GDP and subsequently property investment, but it is not investment by themselves. This situation is considered not to be sustainable and it is evident from the economic downturn that was experienced in South Africa from 2008. If the trend continues, savings will be depleted and this will result in a reduction in consumer spending and subsequently GDP growth, due to a lack of disposable income. The result of this is a downturn economic activity, including direct and indirect real estate investment.

\section{7}

\section{Conclusion}

In the study it is identified that listed property share price behaviour, and more specifically PLS shares, can provide accurate information on the movement in share prices. The accurate correlations shown suggest that the share price could be a surrogate for the asset values. The study is, however, performed within the limits of simple linear correlations, and excludes the combined effect of more than one of these items in a multiple regression. The results are shown to be within the limits of the involvement of shareholders to monitor the activities of the company, which is found to be 
the case with companies having high levels of institutional shareholding. It is furthermore within the limits of long-term views of the share price, as the short-term share price is fluctuating in line with wider JSE sentiment.

As such the study indicates that the relevance of accounting ratios as a method of share valuation for listed property companies is inferior to other methods for determining the value of listed property shares.

The correlation of share prices and subsequently the market capitalisation of the PLS shares with the financial statements of the companies reveals that the assets of the companies, being property, are in themselves the investment. It is therefore stated that the PLS companies are growing by finding opportunities in the market by which they are expanding. By finding these opportunities they create the boundaries of a new playing field, being the share trading market. The investors in the shares of the PLS companies stay within these boundaries, as confirmed by the high correlation between market capitalisation and the balance sheet, and the high correlation of interest payments to investors with the market capitalisation, being the sum of all shares.

The long-term opportunities for the PLS companies are created by the wider economic variables. The GDP growth and various employment levels are seen in close correlation with property market activity, which influences the opportunities that exist for PLS companies.

From this it can be concluded that listed property shares can provide good information on how investors are viewing the balance sheet, or the portfolio of properties of the company itself, which can be used for interpretation of direct property market activity. This should, however, be used cautiously within the parameters of the irrational behaviour of investors, that causes short-term fluctuations in the share prices, and which could distort interpretations. But still it provides the opportunity to get information on property market activity more quickly.

Furthermore, the correlations with economic variables provide the opportunity to also predict property behaviour, based on estimates of future economic activities. This could therefore add to the interpretation of property economics.

The study forms the basis for further research, where the items under review in this paper could be combined in a multiple regression to investigate the possibilities for share prices to explain underlying asset values, and be especially useful in the investigation for multicollinearity.

\section{References}

ARCHOUR-FISCHER, D. 1999. An integrated property market model: a pedagogical tool. Journal of Real Estate Practice and Education, 2(1):33-43.

BOOTH, P.M. \& MARCATO, G. 2004. The dependency between returns from direct real estate and returns from real estate shares. Journal of Property Investment and Finance, 22(2):147-161.

BOSHOFF, D.G.B. 2004. Modelling of the demand for office space in the four major cities in South Africa. Unpublished treatise submitted in fulfilment of a part of the requirements of the MSc (Real Estate), University of Pretoria.

BRENNAN, M.J. 1990. Latent assets. The Journal of Finance, 45(3):709-730.

CASE, B., GOETZMANN, W.N. \& ROUWENHORST, K.G. 2000. Global real estate markets - cycles and fundamentals. National Bureau of Economic Research, Working Paper 7566. 23 pp.

CASE, K.E. \& FAIR, R.C. 1999. Principles of macro-economics $\left(5^{\text {th }}\right.$ ed.) New Jersey: Prentice-Hall.

CHAN, K.C., HENDERSHOTT, P.H. \& SANDERS, A.B. 1990. Risk and return on real estate: evidence from equity REITs, AREUEA Journal, 18(4):431-452.

CHAN, S.H., LEUNG, W.K. \& WANG, K. 1998. Institutional investment in REITs: evidence and implications. Journal of Real Estate Research, 16(3):357-374.

CLAYTON, J. 1996. Market fundamentals, risk and the Canadian property cycle: implications for property valuation and investment decisions. Journal of Real Estate Research, 12(3):347-368.

DIPASQUALE, D. \& WHEATON, W.C. 1992. The markets for real estate assets \& space: a conceptual framework. Journal of the American Real Estate and Urban Economics Association, 20(1):181-197. 
DOPPEGIETER, J. \& RODE, E. 2002. Capitalisation rates and property yields: an analysis of the South African commercial property market. Working paper, School of Business Administration, Bruchsal, Germany, 17 pp.

DOWNS, D.H. \& GÜNER, Z.N. 1999. Is the information deficiency in real estate evident in public market trading? Real Estate Economics, 27(3):517-541.

EDELSTEIN, R.H. \& PAUL, J. 2000. Japanese land prices: explaining the boom-bust cycle. Asia's Financial Crisis and the Role of Real Estate, M.E. Sharpe, London.

FISHER, J.D. 1992. Integrating research on markets for space and capital. Journal of Real Estate and Urban Economics Association, 20(1):161-180.

FISHER, J.D., GELTNER, D.M. \& WEBB, R.B. 1994. Value indices of commercial real estate: a comparison of index construction methods. Journal of Real Estate Finance and Economics, 9:137-164.

GELTNER, D. 1996. The repeated-measures-regression-based idex: a better way to construct appraisal-based indexes of commercial property value. Journal of Real Estate Finance, 12(4):29-35.

GILIBERTO, S.M. 1990. Equity real estate investment trusts and real estate returns. Journal of Real Estate Research, 5(2):259-263.

GLASCOCK, J.L., LU, C. \& SO, R.W. 2000. Further evidence on the integration of REIT, bond and stock returns. Journal of Real Estate Finance and Economics, 20(2):177-194.

GRISSOM, T. \& DELISLE, R. 1999. A multiple index analysis of real estate cycles and structural change. Journal of Real Estate Research, 18(1):97-130.

GYOURKO, J. \& KEIM, D.B. 1993. Risk and return in real estate: evidence from a real estate stock index, Financial Analysts Journal, 49(5):39-46.

HAGER, D.P. \& LORD, D.J. 1985. The property market, property valuations and property performance measurement. Journal of the Institute of Actuaries, 112:19-60.

LEE, S. \& STEVENSON, S. 2007. The substitutability of REITs and value stocks. Applied Financial Economics, 17:541-557.

LING, D.C. \& NARANJO, A. 1997. Economic risk factors and commercial real estate returns. The Journal of Real Estate Finance and Economics, 14(3):283-307.

LING, D.C. \& NARANJO, A. 1999. The integration of commercial real estate markets and stock markets. Real Estate Economics, 27(3):483-515.

LIZIERI, C. \& SATCHELL, S. 1997. Interactions between property and equity markets: an investigation of linkages in the United Kingdom 1972-1992. Journal of Real Estate Finance and Economics, 15(1):11-26. MERA, K. 2000. The linkage of the economy with land price fluctuations: the case of Japan in the 1990s. Asia's Financial Crisis and the Role of Real Estate, M.E. Sharpe, London.

PETERSON, J.D. \& HSIEH, C. 1997. Do common risk factors in the returns on stocks and bonds explain returns on REITs? Real Estate Economics, 25(2):321-345.

QUAN, D.C. \& TITMAN, S. 1999. Do real estate prices and stock prices move together - an international analysis. Real Estate Economics, 27(2):183-207.

RENAUD, B. 1997. The 1985 to 1994 global real estate cycle: an overview. Journal of Real Estate Literature, 5(1):13-44.

SAGALYN, L.B. 1990. Real estate risk and the business cycle: evidence from security markets. Journal of Real Estate Research, 5(2):203-219.

SHILLER, R.J. 2003. From efficient markets theory to behavioural finance. Journal of Economic Perspectives, 17(1):83-104.

VAN HEERDEN DE WET, J.H. 2004. A strategic approach in managing shareholders' wealth for companies listed on the JSE securities exchange South Africa. Doctoral Dissertation, University of Pretoria, South Africa.

VIEZER, T.W. 1998. Statistical strategies for real estate portfolio diversification. Doctoral Thesis, Ohio State University, Columbus, $\mathrm{OH}$.

VIEZER, T.W. 1999. Econometric integration of real estate's space and capital markets. Journal of Real Estate Research, 18(3):503-519.

WILSON, P.J. \& ZURBRUEGG, R. 2003. Isolating important driving forces in indirect real estate markets. Journal of Real Estate Portfolio Management, 9(3):205-218. 